\title{
THE IMPACT OF CLIMATE CHANGE ON THE WATER REGIME IN THE VRBANJA RIVER BASIN
}

DOI: https://doi.org/10.18509/GBP210111r

UDC: 551.583:556.535(497.6)

\author{
Vesna Rajčević \\ Tanja Mislicki-Tomić \\ Faculty of Natural Sciences and Mathematics, University of Banja Luka, \\ Republic of Srpska, Bosnia and Herzegovina
}

\begin{abstract}
Essentially, climate is a natural framework within which its impact on water resources in a specific geographic area is being monitored and defined; the focus of the paper is the Vrbanja River Basin. Climate elements such as precipitation and those which increase the evaporation and decrease the amount of water flowing into water streams, such as air temperature, air humidity and wind frequency and speed, are crucial for changes in the watercourse supply.

The analysis of climate elements suggests that the Vrbanja Basin is characterized by temperate continental climate with harsh winters and warm summers, making the basin a part of pluvio-nival regime belonging to a larger system of the Sava River Basin. Air temperature and precipitation are basic climate elements which largely determine hydrological processes and water balance of a specific basin.

The Vrbanja River is one of the largest right tributaries of the Vrbas River and one of the most pertinent autochthonous water streams in the Republic of Srpska. The Vrbanja Basin covers $791.33 \mathrm{~km} 2$. The dominant direction of the elongated Vrbanja watershed is southeast-northwest. The river flow is $96.30 \mathrm{~km}$ long, and the length of the watershed is $97.18 \mathrm{~km}$ with the maximum width of $30.4 \mathrm{~km}$. The total decline of the Vrbanja River flow is $1371 \mathrm{~m}$, which indicates a strong geogenic and anthropogenic differentiation of the watershed area.

The paper analyzes data on basic climate elements (air temperature and precipitation) in the Vrbanja River Basin from 1961 to 2015 and the impact which the variations of these elements might have had on the river regime. The data on the Vrbanja River regime (water level and flow rate) are analyzed during the period 1926-2019. The analysis suggests that there has been a constant increase in air temperature, especially from 2010 onwards, and that the precipitation timeline has been changing. Given that water is directly connected to climate, each modification in climate parameters directly affects the water regime. The extremes were documented in 2014 when the highest ever water level $(592 \mathrm{~cm})$ and water flow $(843.8 \mathrm{~m} 3 / \mathrm{s})$ on the Vrbanja River were registered. The results were catastrophic floods in both the Vrbanja River Basin and the neighboring areas.

The registered increase in mean air temperature, especially over the last decade, is one of the best indicators of global climate change. Consequences of the air temperature increase are many and may involve high flood and drought risks, the decline of snow coverage, the loss of biodiversity, or threats to human health and life.
\end{abstract}

Keywords: the Vrbanja River Basin, climate change, water level, water flow, trends. 


\section{INTRODUCTION}

In the late 20th and early 21 st centuries, the global warming trend continues. The Earth atmosphere and oceans are getting warmer, the snow and ice layers are melting, and the sea level is increasing [1]. The resulting risks and negative effects are many and very likely to intensify. Europe is expected to encounter massive effects of global warming in the decades to come [2]. Threats to both humans and the environment will largely be related to the extreme climate event changes, which occur due to an increase in their intensity and frequency different than normal[3].

Global studies on climate change suggest that there has been a large global air temperature increase, whereas the annual precipitation values display a decreasing trend in the Mediterranean climate zone and an increasing trend in North Europe.

Global annual air temperature has grown since 1880 with an average growth rate of 0.07 ${ }^{\circ} \mathrm{C}$ per decade [4]. It is in the northern latitudes that the warming has been most pronounced over the last few decades [5].

The last thirty years were the warmest over the entire observed period. Each decade was successively warmer than the previous one, and the first decade in the 21 st century was the warmest ever since 1850 [6],[1]. It is in the 21st century that fifteen out of sixteen warmest years during the observed period were recorded. 2015 was the warmest year and 2011-2015 was the warmest five-year period [7].

Annual and seasonal air temperature analyses in Serbia, Croatia, Slovenia, Montenegro, and Greece indicate significant positive trends in most of the region in the second half of the 20th and early 21st centuries [10],[8],[11],[9]. Previous studies conducted in some Bosnia and Herzegovina regions [12],[13],[14],[15] suggested that there was a positive trend of air temperature in the country.

The last few years have witnessed the impact of climate change on the precipitation regime.

Linear trends for the period 1961-2015 suggested that the amount of precipitation in Bosnia and Herzegovina either stagnated or slightly increased and that changes were more evident seasonally rather than annually. Despite the fact that there were no significant changes in the amount of precipitation, the pluviometric regime and the annual distribution were largely affected.

Climate change has a great impact on Bosnia and Herzegovina's rivers' regime, which is evident in frequent extremely dry and watery periods largely affecting both water supplies and human health. [16]. Consequently, the dry periods last longer and the precipitation intensity grows, causing floods. In areas of mountain and hilly terrain, the rainfall quickly outpours over the ground surface after which the drought increases the water deficit. The consequences are enormous as they affect the agriculture, plant growth, biodiversity, water balance, and water supplies in Bosnia and Herzegovina [17].

The flood risk is particularly high in north-east Bosnia and Herzegovina, where the most catastrophic flood in history occurred in 2014.

The water flow is negatively correlated with air temperature during the entire year (with a short exception in the winter), whereas there is a significant positive correlation with precipitation [18].

Earlier studies conducted in south-east Europe registered strong changes in the river flow rates in some parts of the region [19]. A significant negative trend of both annual and seasonal flow rates was registered in the entire Serbian territory (in all seasons except autumn) [20]. A significant decrease of average flow rates was monitored in most rivers in Slovenia [21]. In Croatia, the flow rate increased in the autumn and winter, and 
decreased in the summer [22]. Results of studies conducted in Macedonia suggested that there were significant negative seasonal trends in flow rates in the entire country [23]. Nevertheless, local climate change should be observed as a consequence of the global change, but still depending on local impacts (latitude and longitude, topography, altitude). It is the climate elements (precipitation and other elements affecting the decrease of water amounts by causing evaporation, such as air temperature, air humidity, wind speed) that clearly have the strongest impact on the water stream recharge [24]. Hence, the paper will analyze modern changes in air temperature and precipitation and the effect they have on the flow rate and water level changes in the Vrbanja River Basin.

\section{DATA AND METHODS}

The Vrbanja River Basin is located in central Bosnia and Herzegovina, west Republic of Srpska (south-east Banja Luka nodal-functional region). It is positioned between $44^{\circ} 47^{\prime} 39^{\prime \prime}$ and $44^{\circ} 20^{\prime} 44^{\prime \prime} \mathrm{N}$ north latitude and $17^{\circ} 12^{\prime} 33^{\prime \prime}$ and $17^{\circ} 14^{\prime} 42^{\prime \prime} \mathrm{E}$ east longitude. The Vrbanja River is one of the longest right Vrbas tributaries and one of the most pertinent autochthonous water streams in the Republic of Srpska. The Vrbanja River Basin covers nearly $99.7 \%$ of the Republic of Srpska's territory and $0.3 \%$ (the river source) of the water stream is located in the Federation of Bosnia and Herzegovina.

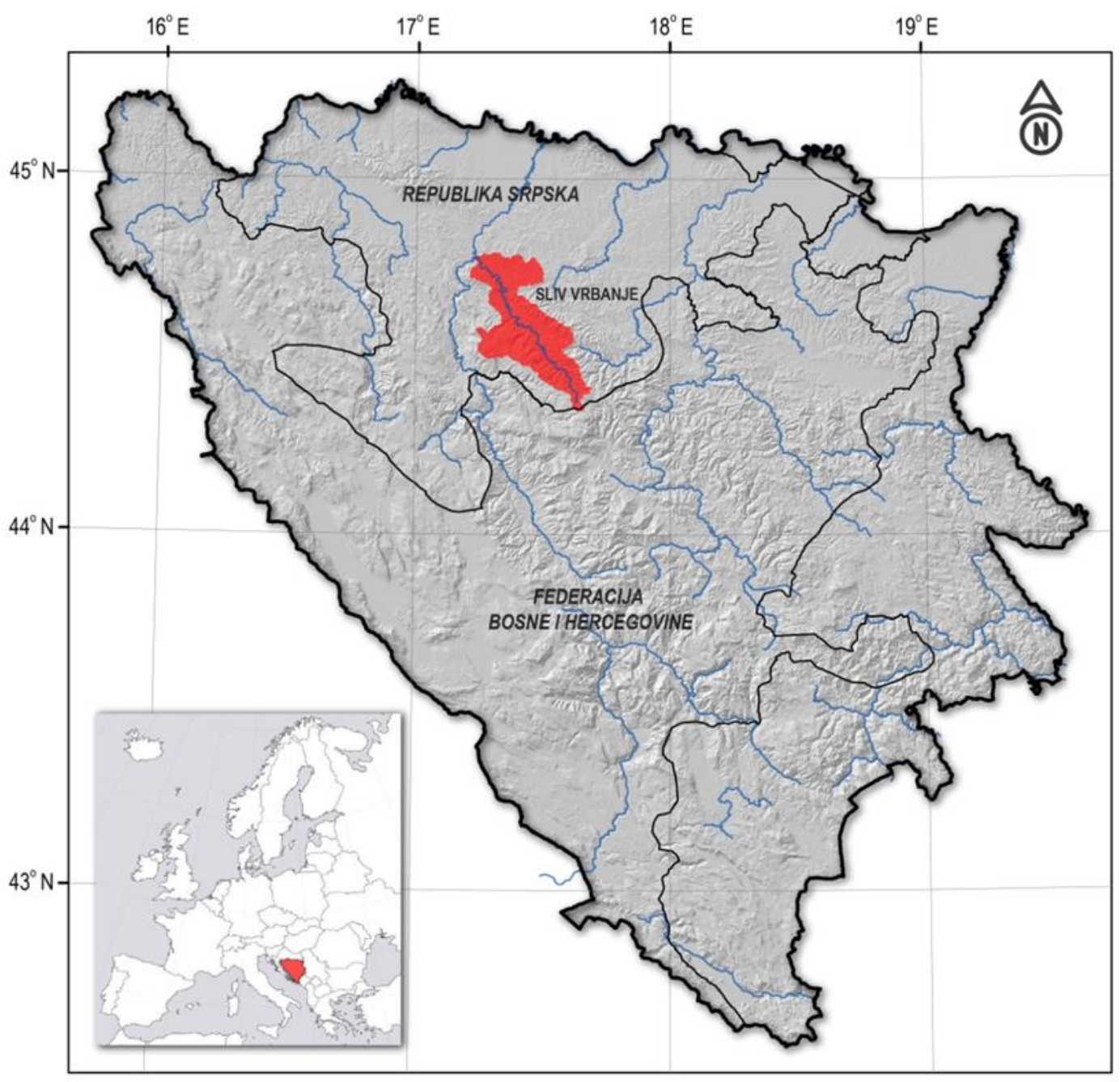

Figure 1. Geographic position of the Vrbanja River Basin. 
The Vrbanja River Basin is located at the contact point between two macro regions - the highland region and the Pannonian region. The source of the Vrbanja River is located at the Vlasic Mountain (1563 m altitude) and the river mouth is located near the City of Banja Luka (147 m altitude) [25].

The topographic surface of the Basin covers $791.33 \mathrm{~km}^{2}$. The dominant direction of the elongated Vrbanja watershed is southeast-northwest. The river flow is $96.30 \mathrm{~km}$ long, and the watershed length is $97.18 \mathrm{~km}$ with the maximum width of $30.4 \mathrm{~km}$. The total decline of the Vrbanja River flow is $1371 \mathrm{~m}$, which indicates a strong geogenic and anthropogenic differentiation of the watershed area.

The statistical analysis of climate elements found that the Vrbanja River Basin is characterized by moderate continental climate, with cold winters and warm summers. Accordingly, the basin belongs to the pluvio-nival regime, Posavina type, with highest water levels in April and lowest water levels in August.

The Vrbanja hydrological observation station was founded in 1922 and it is under the jurisdiction of the Hydrometeorological Institute of the Republic of Srpska. The station is located $8.33 \mathrm{~km}$ upstream from the Vrbanja River mouth into the Vrbas. The topographic point „OO“, where the water gauge is installed, is set at $166.22 \mathrm{~m}$ altitude.

During the last war in Bosnia and Herzegovina (1992-1995), the measurement and monitoring at the Vrbanja hydrological station suffered long interruptions. Data for the years of 1991, 1993, 1994, 1995 and 1996 are either incomplete or none, so these years are excluded from our analysis.

The paper analyzes the air temperature and precipitation fluctuations and their impact on the Vrbanja River regime. The data used in the analysis were collected from Banja Luka meteorological station during the period 1961-2015. The moving average method was used to analyze climate elements and the river regime. The purpose of the method was to annul the shortest lasting fluctuations related to annual time intervals and point out the fluctuations covering several-year periods [26]. Recent studies suggest that it is most productive to use sequences of moving average obtained by five-year mean values. The following formula was used [26]:

$X_{n+1}=X_{n}\left(X_{6+n}-X_{n}\right): 6$, in which

$X_{n}=1 / 6 \sum_{i=1}^{n+5} X_{i}$

$X_{i}$ - individual value per a year;

$\mathrm{n}=0,1,2,3, \ldots \mathrm{m}$ - the observed year range in which $\mathrm{m}$ stands for a five-year time interval. The analysis of climate variations and changes in air temperature and precipitation is presented on the basis of decade and seasonal values. The timeline for average annual air temperature values and the amount of precipitation with differentiated trends during the periods 1961-2015 (referential sequence) and 1991-2015 is presented.

The Vrbanja River regime was defined based on the water level and flow rate. The regime was analyzed via data collected at the Vrbanja hydrological observation station from 1926 to 2019. Current trends of average annual and seasonal water levels and flow rates were estimated. The Pearson correlation coefficient was used to determine interdependency between the climate elements and water flow rate.

In order to estimate the annual deviation from the average flow rate (i.e. the occurrence of less or more watery years), the years were ranked in line with wateriness [19]. This method enables the monitoring of changes in a river's water regime. The application of 
the method in hydrological and geographical studies helps register trends of wateriness in a water stream. [27]. Based on the average annual flow rate and its standard deviations during the analyzed period, years were ranked in line with wateriness as follows [28]:

$-<-3 \delta$ Catastrophically dry year

$--3 \delta--2 \delta$ Very dry year

$--2 \delta--1 \delta$ Dry year

$--1 \delta-1 \delta$ Average wateriness

- $1 \delta-2 \delta$ Watery year

- $2 \delta-3 \delta$ Very watery year

- $>3 \delta$ Catastrophically watery year

\section{RESULTS AND DISCUSSION}

\section{The analysis of air temperature fluctuations}

The aforementioned formula was used to calculate a series of the moving average for air temperature, as presented in Figure 2. The average annual air temperature during the period $1961-2015$ was $11.2^{\circ} \mathrm{C}$. The average annual air temperature trend is positive with a tendency of increase at $0.46{ }^{\circ} \mathrm{C}$ rate per decade. Specific air temperature fluctuations are evident. The five-year moving average clearly indicates that there were several different time periods with pronounced temperature fluctuations.

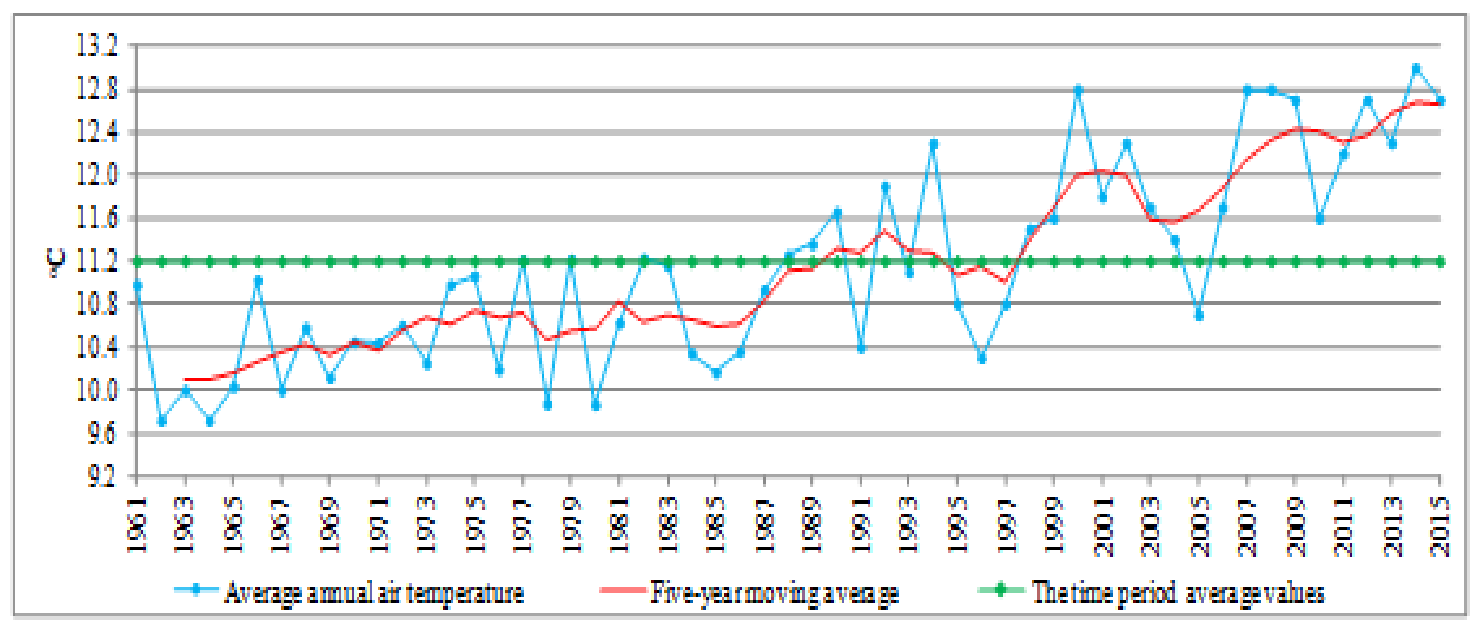

Figure 2. The air temperature fluctuations at the Banja Luka meteorological station during the period 1961-2015

The first period lasted the longest, from 1961 to 1988, and the air temperature was above the multiannual average. The second period lasted from 1988 to 1992 , and the air temperature was slightly above the multiannual average. The third period lasted from 1992 to 1997, and the fourth period lasted from 1997 to 2015 (the air temperature had a tendency of constant growth). The year of 2014 was the warmest within the observed period with the average annual air temperature of $13{ }^{\circ} \mathrm{C}$. 


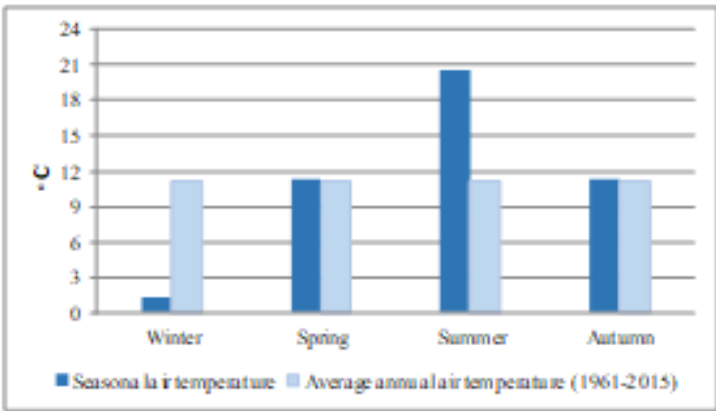

Figure 3. The average seasonal and annual air temperatures at the Banja Luka meteorological station

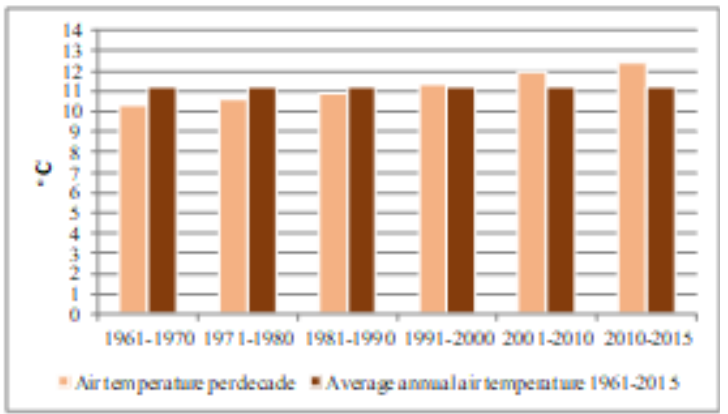

Figure 4. The average decade and annual air temperatures at the Banja Luka meteorological station

The analysis of seasonal air temperature found that the warmest month was July $\left(21.4{ }^{\circ} \mathrm{C}\right.$ average $)$, and the coldest one was January $\left(0.2^{\circ} \mathrm{C}\right.$ average). The seasonal average of 11.4 ${ }^{\circ} \mathrm{C}$ made the spring slightly warmer than the autumn $\left(11.3^{\circ} \mathrm{C}\right)$.

Figure 4 shows that there is a trend of the air temperature increase per decade and each decade is warmer than the previous one. In the last two decades, the recorded air temperature was $1{ }^{\circ} \mathrm{C}$ higher than the multiannual average and in the first four decades, the recorded air temperature was $0.4{ }^{\circ} \mathrm{C}$ lower than the multiannual average, during the observed period.

Figure 5 displays the timeline of average annual air temperature with differentiated trends for the whole observed period, during the periods 1961-1990 (referential sequence) and 1991-2015. There is an evident intensification of the trend for the last 55 years. The deviations from the average annual air temperature during period 1961-1990 are increasing. The period $1991-2015$ was $1.2^{\circ} \mathrm{C}$ warmer than the "referential sequence" and $0.6^{\circ} \mathrm{C}$ warmer than the multiannual average.

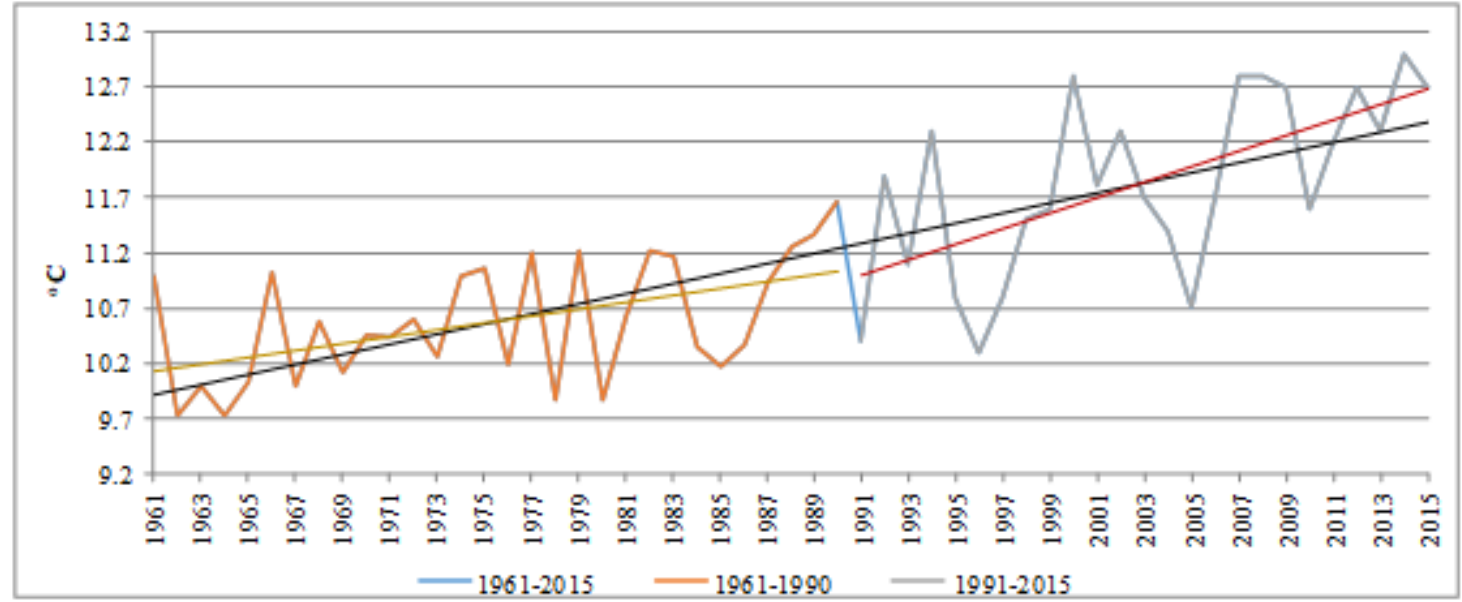

Figure 5. The air temperature deviation trends in specific periods

\section{The analysis of precipitation fluctuations}

The pluviometric regime of the Vrbanja River Basin is under a large impact of maritime air masses from the west (the Atlantic Ocean) and the south (the Mediterranean), and the orographic properties of the local area. The local impact is most evident in the summer when the pluviometric regime is affected by the local air depression accompanied by downpours. Studying precipitation fluctuations is one of the fundamental indicators of the water regime of the Vrbanja River and its tributaries. 
A series of the moving average for the amount of precipitation calculated using the abovementioned formula is presented in Figure 6.

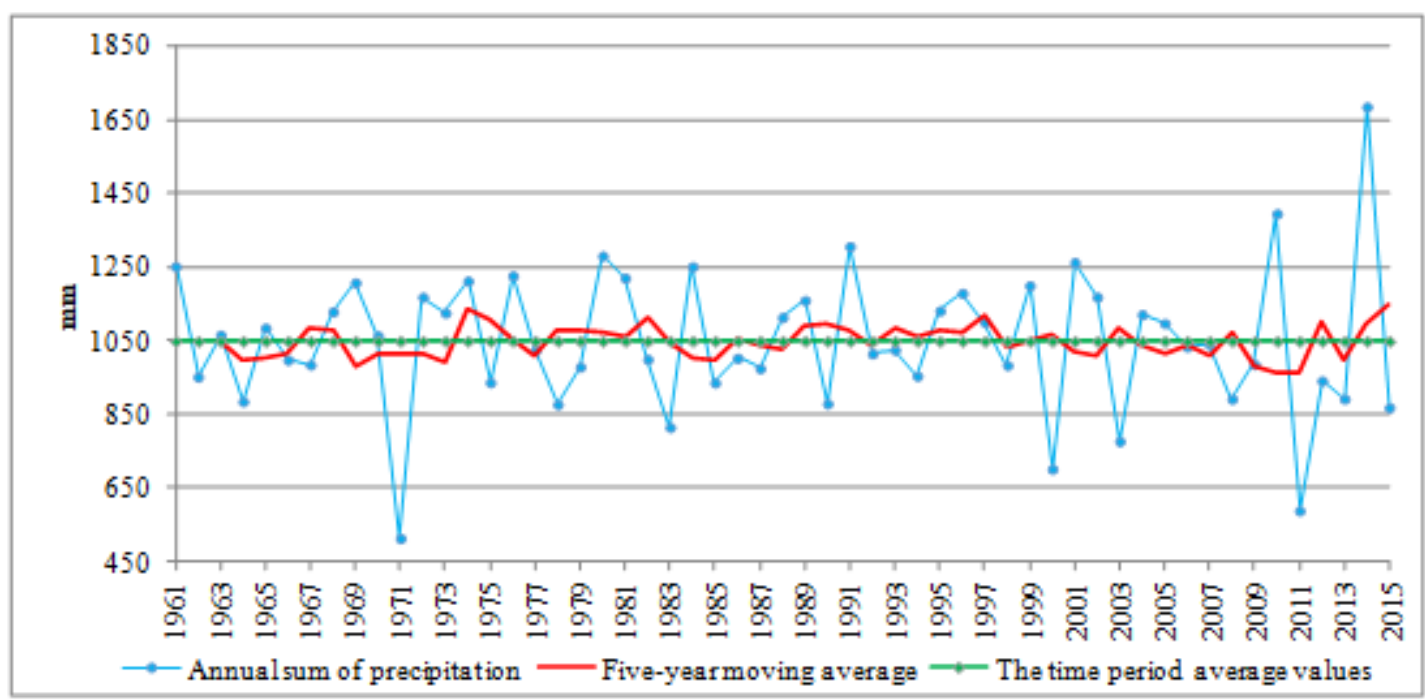

Figure 6. Fluctuations of the amount of precipitation at the Banja Luka meteorological station during the period 1961-2015.

The mean value of the sum of precipitation is $1049 \mathrm{~mm}$, but there is an evident fluctuation of the multiannual average. The results show that the trend of the average amount of precipitation is negative with a tendency of decline $(-4,33 \mathrm{~mm}$ per decade). The five-year moving average suggests that there are several different periods with intensive precipitation fluctuations. The first period lasted from 1961 to 1969 and the precipitation amount was around the multiannual average. The second period lasted from 1969 to 1974 and the precipitation amount was below the multiannual average. The third period lasted from 1974 to 1982 and the precipitation amount was slightly above the multiannual average. The precipitation amount was below the average during the fourth period (19821989). During the fifth period (1989-2000), the precipitation amount fluctuation was around the annual average. The sixth period (2000-2011) registered the trend of decline of the amount of precipitation. It was in this period that the two driest years were recorded (2003 and 2011). The latest fluctuation period started in 2011 and the precipitation fluctuation was evident. The amount of precipitation in $2014(637,2 \mathrm{~mm})$ was higher than the annual average, resulting in catastrophic floods with human losses and material damages

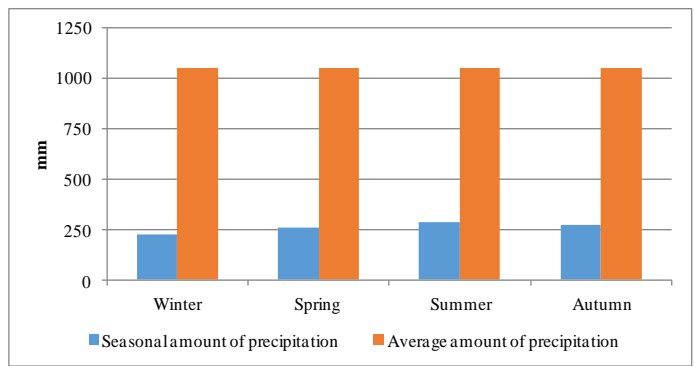

Figure 7. The average seasonal and annual amount of precipitation at the Banja Luka meteorological station

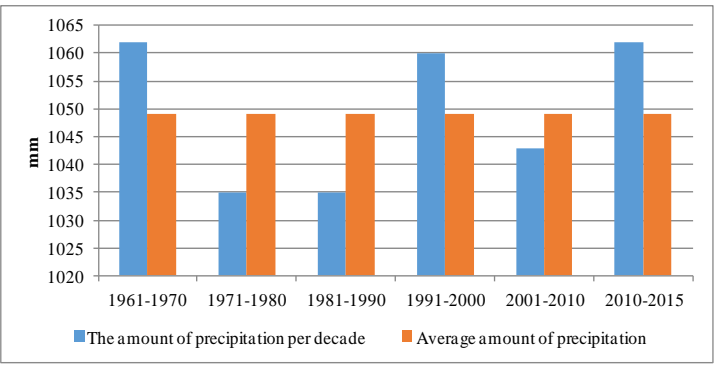

Figure 8. The average decade and annual amount of precipitation at the Banja Luka meteorological station 
The analysis of the seasonal amount of precipitation suggested that June $(107,4 \mathrm{~mm})$ and May $(94,4 \mathrm{~mm})$ were the months with most rains. The autumn had the seasonal average of $276 \mathrm{~mm}$, which made it more humid than the spring $(260 \mathrm{~mm})$. Figure 8 shows that the first and the last decades had the equal amounts of precipitation with most evident annual fluctuations.

\section{The analysis of the water level fluctuations}

The Vrbanja hydrological observation station has had reliable hydrological monitoring instruments since 1922. The period 1926-2019 was used for the purpose of analysis of water level and flow rate of the Vrbanja River. The methodology used for the studying of water level and flow rate matches the methodology used for the analysis of climate elements.

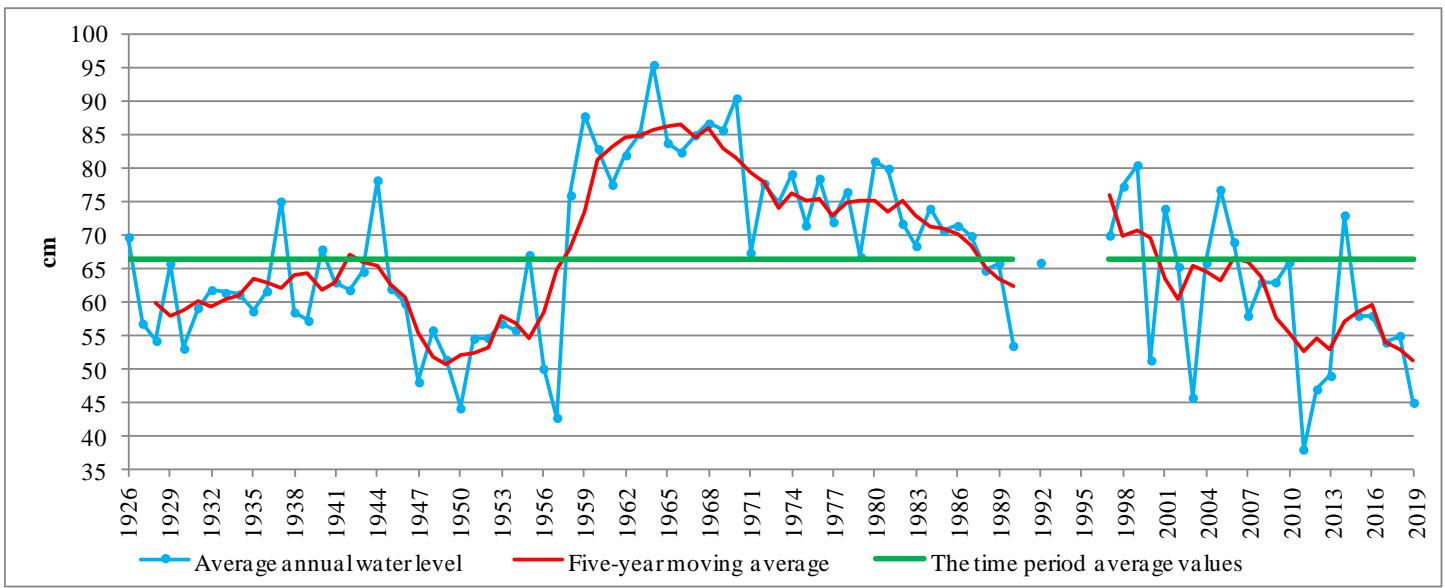

Figure 9. The fluctuations of water levels at the Vrbanja hydrological station during the period 1926-2019

Based on the aforementioned formula, the series of moving average of water levels is presented in Figure 9. The average water level during our target period was $66,28 \mathrm{~cm}$. The highest water level was registered in May 2014 (592 cm), and the lowest water levels were registered in July, August, September and October. It was in April and May that the water levels were the highest. The average monthly precipitation values result from the cyclic downpours in May, June and July. In other words, the summer downpours cause the short-lasting high water levels. The high water level is also caused by the snow melting in the spring, especially in the Vlasic Mountain area.

The trend of the average annual water level is negative, with a tendency of decline $(-0,75$ $\mathrm{cm}$ per decade). The five-year moving average clearly shows that there are several different periods with pronounced water level fluctuations. The first period of the water level fluctuation lasted from 1926 to 1936 with the water level below the multiannual average. The second period lasted from 1936 to 1944 and the values were mostly below the average. The third period lasted from 1944 to 1957 with values far below the average. The fourth period lasted from 1957 to 1971 and the water level largely increased. The fifth period lasted from 1971 to 1991, when the water level had a tendency of decline but the values were above the average. Even though the period 1990-1997 was not monitored (except in 1992), there were indications of the declining water level. The sixth period of the water level fluctuation lasted from 1997 to 2005 and a tendency of decline was observed. It was in this period that one of the driest years occurred (2003). The last, 
seventh period of water level fluctuations started in 2003 and is still pending. It was in 2011 that the lowest water level at the Vrbanja hydrological observation station was recorded $(38 \mathrm{~cm})$. The Vrbanja River and its tributaries are relatively small and the usage of their water stream potential is limited due to the fluctuations of the hydrological regime. During the dry periods, the Vrbanja River water level and flow rate are minimal, particularly in the upper and middle streams. During the intense recharge (snow melting and heavy rainfalls), the river stream turns into a torrent and is polluted by both mineral and organic materials.

\section{The analysis of water flow rate fluctuations}

The calculated series of the moving average for water flow rate is presented in Figure 10. The average flow rate during the observed period was $15,26 \mathrm{~m} 3 \mathrm{~s}$. The trend of average annual flow rates was negative, with a tendency of decline (-3,08 m3s per decade).

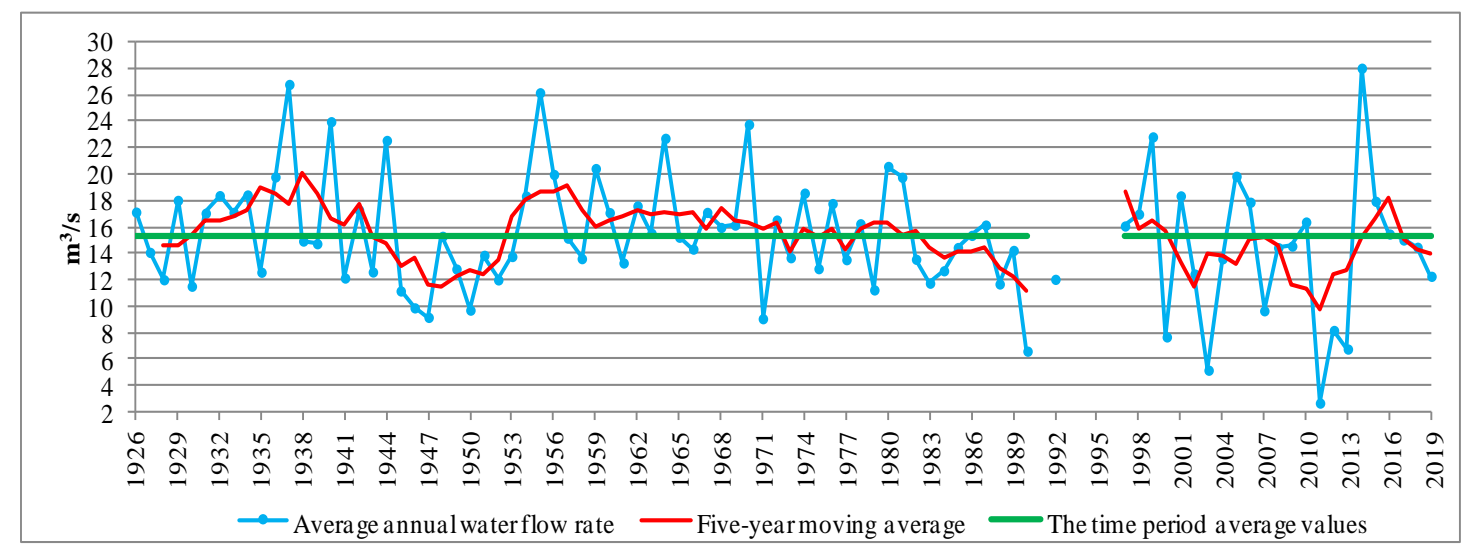

Figure 10. The water flow rate fluctuations at the Vrbanja hydrological observation station from 1926 to 2019

The five-year moving average clearly indicates that there were several different periods with pronounced flow rate fluctuations. The first period lasted from 1926 to 1936 with significant fluctuations in regard to multiannual average. The second period lasted from 1936 to 1950 and was characterized by great wateriness. The third period lasted from 1950 to 1970 and the significant fluctuations were mostly above the multiannual average. The fourth period lasted from 1970 to 1986, and the values were largely below the average. The fifth period lasted from 1986 to 1997, and the flow rates were low. The sixth period with pronounced fluctuations lasted from 1997 to 2005, and the flow rates were extremely low. It was during this period that one of the driest years was recorded (5.18 $\mathrm{m} 3 \mathrm{~s}$ flow rate). The latest, seventh period lasted from 2005 to 2019, and during this period the driest year ever was recorded (2011) with only $2.69 \mathrm{~m} 3 \mathrm{~s}$ flow rate. The last period is characterized by another extreme value: the highest flow rate ever recorded. It was registered in May 2014 and was $843.8 \mathrm{~m} 3 \mathrm{~s}$.

The Pearson correlation coefficient found a statistically significant positive correlation between precipitation and flow rate $(+0.633)$ and statistically poor correlation between air temperature and flow rate (-0.295).

Figure 11 displays a high correlation in regard to quantitative values of the average annual amount of precipitation and average annual flow rates. 


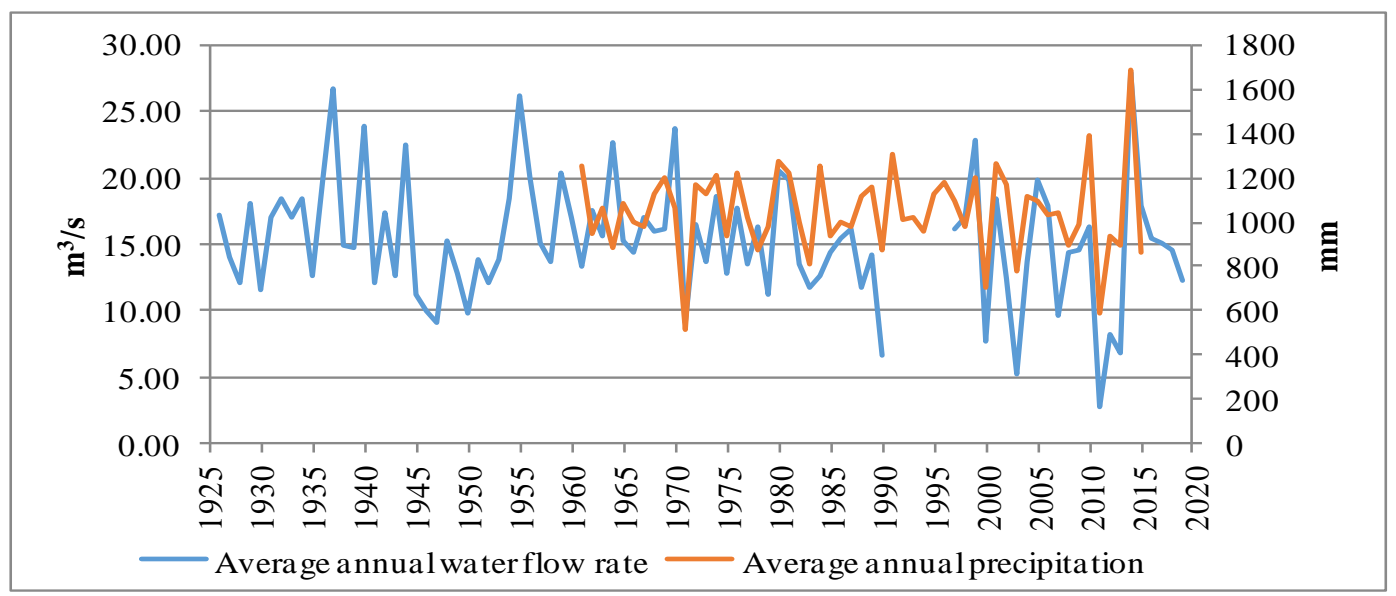

Figure 11. Ratio between precipitation and flow rates.

The causes of floods in the Vrbanja River Basin are long heavy rainfalls and sudden snow melting, very often combined. The distribution and volume of high water levels in the Vrbanja Basin essentially depend on the dry and watery periods. Table 1 shows the year ranking in line with wateriness according to data from the Vrbanja hydrological station during the period $1926-2019$.

Table 1. Quantitative and percentage ratio of specific years per wateriness categories according to the records from the Vrbanja hydrological observation station from 1926 to 2019 (years without monitoring are not included)

\begin{tabular}{|l|l|l|}
\hline Vrbanja hydrological station & Number of years & $\%$ \\
\hline Rank & - & - \\
\hline Catastrophically dry & 2 & 2.3 \\
\hline Very dry & 9 & 10.2 \\
\hline Dry & 63 & 71.6 \\
\hline Average wateriness & 11 & 12.5 \\
\hline Watery & 3 & 3.4 \\
\hline Very watery & 0 & - \\
\hline Catastrophically watery & 88 & 100 \\
\hline Total & \multicolumn{2}{|l|}{} \\
\hline
\end{tabular}

Table 2. The year ranking in line with wateriness as recorded at the Vrbanja hydrological observation station from 1926 to 2019

\begin{tabular}{|c|c|c|}
\hline Rank & /Discharge Qsr $\left(\mathrm{m}^{3} \mathrm{~s}\right)$ & Year \\
\hline $\begin{array}{l}\text { Catastrophical } \\
\text { ly dry }\end{array}$ & $<2.69$ & - \\
\hline Very dry & $2.69-5.18$ & 2011,2003 \\
\hline Dry & $5.18-9.90$ & $1990,2013,2000,2012,1971,1947,2007,1950,1946$ \\
\hline $\begin{array}{l}\text { Average } \\
\text { wateriness }\end{array}$ & $9.90-18.59$ & $\begin{array}{l}1974,1934,1932,2001,1954,1929,2015,2006,1976,1962, \\
1942,1926,1967,1933,1960,1931,1998,1972,2010,1978,1 \\
9871969,1997,1968,1963,20116,1986,1948,1965,1957, \\
2017,1938,1939,2009,2018,1985,2008,1966,1989,1927, \\
1951,1953,1973,1958,2004,1982,1977,1961,1975,1949, \\
1984,1943,1935,2002,019,1941,1992,1928,1952,1983, \\
1930,1979,1945\end{array}$ \\
\hline Watery & $18.59-24.00$ & $\begin{array}{l}\text { 1940,1970,1999,1964,1944,1980,1959,1956,2005,1936, } \\
1981\end{array}$ \\
\hline Very watery & $24.00-28.05$ & $1955,1937,2014$ \\
\hline $\begin{array}{l}\text { Catastrophical } \\
\text { ly watery }\end{array}$ & $>28.05$ & - \\
\hline
\end{tabular}




\section{CONCLUSION}

The paper analyzed recent changes in air temperature and precipitation as well as their impact on the flow rate and water level fluctuations in the Vrbanja River Basin. In order to annul the variation of the annual values for the analyzed parameters, five-year values were taken into account. Accordingly, different time frames (ranging from 4 to 27 years), within which a complete fluctuation occurred, may be singled out for each of the analyzed parameters.

The average annual air temperature trend is positive with a tendency of growth $\left(0.46^{\circ} \mathrm{C}\right.$ per decade). Specific air temperature fluctuations are evident and this trend has intensified over the last 55 years. The seasonal air temperature analysis showed that the warmest month was July $\left(21.4{ }^{\circ} \mathrm{C}\right.$ in average) and the coldest one was January $\left(0.2{ }^{\circ} \mathrm{C}\right)$. The average seasonal air temperature value of $11.4^{\circ} \mathrm{C}$ makes the spring slightly warmer than the autumn $\left(11.3^{\circ} \mathrm{C}\right)$.

The precipitation regime has been changing quickly. There are long dry periods on one side and intensive precipitation causing floods on the other side. Furthermore, extreme events and records in regard to other climate parameters have been more pronounced.

Our results show that the trend of changes in the average amount of precipitation is negative, with a tendency of decline $(-4.33 \mathrm{~mm}$ per decade).

Recent climate change has greatly affected the water level and flow rate in the Vrbanja River Basin. The trend of changes in the average annual water level is negative with a tendency of decline $(-0.75 \mathrm{~cm}$ per decade). The highest water level was registered in May $2014(592 \mathrm{~cm})$ during catastrophic local floods. It was in 2011 that the lowest water level was measured (only $38 \mathrm{~cm}$ ). The Vrbanja River and its tributaries are relatively small rivers and the exploitation of the water stream is limited due to changes in hydrological regime. The years 2003 and 2011 were most affected by drought during the analyzed period.

The trend of changes in the average annual water flow during the analyzed period is negative, with a tendency of decline $\left(-3.08 \mathrm{~m}^{3} \mathrm{~s}\right.$ per decade). The highest water flow rate was registered in May $2014\left(843.8 \mathrm{~m}^{3} \mathrm{~s}\right)$.

The causes of high water levels and flooding in the Vrbanja watershed are long, heavy rainfalls and sudden snow melting, especially when they combine. There is a strong negative correlation between the water flow and air temperature during a whole year (with a short exception in the winter), but the correlation between the water flow and precipitation is significant and positive.

The Pearson correlation coefficient measured a statistically significant positive correlation between precipitation and water flow (+0.633) and a statistically insignificant negative correlation between air temperature and water flow (-0.295).

The distribution and volume of water in the Vrbanja River Basin largely depend on dry and watery periods. Speaking of ranking years in line with wateriness, $71.6 \%$ of the analyzed years are of the average wateriness.

\section{REFERENCES}

[1] Intergovernmental Panel on Climate Change [IPCC] (2014). Climate change 2014: Impacts, Adaptation, and Vulnerability. Part A: Global and sectoral aspects. Contribution of Working Group II to the Fifth Assessment Report of the Intergovernmental Panel on Climate Change [Field, C. B., Barros, V. R., Dokken, D. J., Mach, K. J., Mastrandrea, M. D., Bilir, T. E., Chatterjee, M., Ebi, K. L., Estrada, Y. O., Genova, R. C., Girma, B., Kissel, E. S., Levy,A. N., 
MacCracken, S., Mastrandrea, P. R. \& White, L. L. (eds.)]. Cambridge and New York: Cambridge University Press.

[2] Kreibich, H., van den Bergh, J., Bouwer, L. et al. Costing natural hazards. Nature Clim Change 4, 303-306 (2014). https://doi.org/10.1038/nclimate2182

[3] Rummukainen M (2012) Changes in climate and weather extremes in the 21st century. Wiley Interdiscip Rev Clim Chang 3:115-129. doi:10.1002/wcc.160

[4]Hansen, J., M. Sato, R. Ruedy, K. Lo, D.W. Lea, and M. Medina-Elizade, 2006: Global temperature change. Proc. Natl. Acad. Sci., 103, 14288-14293, doi:10.1073/pnas.0606291103.

[5] McGregor, S., Timmermann, A., Stuecker, M. et al. Recent Walker circulation strengthening and Pacific cooling amplified by Atlantic warming. Nature Clim Change 4, 888-892 (2014). https://doi.org/10.1038/nclimate2330

[6] Hartmann, D. L., Klein Tank, A. M. G., Rusticucci, M., Alexander, L. V., Brönnimann, S., Charabi, Y. A. R., Dentener, F. J., Dlugokencky, E. J., Easterling, D. R., Kaplan, A., Soden, B. J., Thorne, P. W., Wild, M., \& Zhai, P. (2013). Observations: Atmosphere and surface. In Climate Change 2013 the Physical Science Basis: Working Group I Contribution to the Fifth Assessment Report of the Intergovernmental Panel on Climate Change (Vol. 9781107057999, pp. 159-254). Cambridge University Press. https://doi.org/10.1017/CBO9781107415324.008

[7] National Oceanic and Atmospheric Administration Climate Prediction Center [NOAA CPC] (2017). Northern Hemisphere Teleconnection Patterns. Retrieved October 15, 2017 from http://cpc.ncep. noaa.gov/data/teledoc/telecontenst.shtml

[8] Branković, Č., Güttler, I. \& Gajić-Čapka, M. (2013). Evaluating Climate Change at the Croatian Adriatic from Observations and Regional Climate Models' Simulations. Climate Dynamics, 41(9-10), 2353-2373.

[9] Burić, D., Luković, J., Bajat, B., Kilibarda, M. \& Živković, N. (2015b). Recent Trends in Daily Rainfall Extremes over Montenegro (1951-2010). Natural Hazards and Earth System Sciences, 15, 2069-2077.

[10] Ducić, V., Luković, J., Burić, D., Stanojević, G. \& Mustafić, S. (2012). Precipitation Extremes in the Wettest Mediterranean Region (Krivošije) and Associated Atmospheric Circulation Types. Natural Hazards and Earth System Sciences, 12, 687-697

[11] Milošević, D.D., Savić, S.M., Pantelić, M., Stankov, U., Žiberna, I., Dolinaj, D. \& Leščešen, I. (2016). Variability of Seasonal and Annual Precipitation in Slovenia and Its Correlation with Large-Scale Atmospheric Circulation. Open Geosciences, 8, 593-605.

[12] Trbić, G., Bajić, D. 2011. Specifics of the Climate Change in the Republic of Srpska and Adaptation Options. 3rd Congress of Serbian Geographers with interna-tional participation, Collection of papers, pp. 149-157. (in Serbian with English summary)

[13] Trbić, G. 2013. Climate Variations in the Republic of Srpska. In: Gnjato, R. 20th anniversary of the Re-public of Srpska Geographical Society 1993-2013, Collection of papers, pp. 87-95. (in Serbian with English summary)

[14] Popov, T., Trbić, G. 2015. The Air Temperature Anal-ysis of the Continental Biogeographical Region in the Republic of Srpska. 4th Serbian Congress of Geographers with international participation "Achievements, Current Topics and Challenges of Geographical Science and Practice", Collection of papers (Book1), pp. 115-120. (in Serbian)

[15]Popov, T., Živak, N. 2016. Potential Effects of Recent Climate Change on Agricultural Production in Semberija. 6th International Academic Symposi-um Local Self-Government in Planning and Reg-ulation of Space and Settlements: Towards Europe-an Integration, Collection of papers, pp. 381-388. (in Serbian) 
[16] Crnogorac C., Rajcevic V. (2019) Climate Change and Protection Against Floods. In: Leal Filho W., Trbic G., Filipovic D. (eds) Climate Change Adaptation in Eastern Europe. Climate Change Management. Springer, Cham. https://doi.org/10.1007/978-3-030-03383-5_9

[17]. Spasova D., Trbić G., Ž.Majstorović (2007): Studija procjene uticaja klimatskih promjena na poljoprivredu i razvoj strategije adaptacije u Bosni i Hercegovini \{Study for Climate change impact assessement on agriculture and adaptions strategy development in Bosnia and Hercegovina\}, Vlada Republike Srpske, Ministarstvo za prostorno uređenje, građevinarstvo i ekologiju, Regionalni centar za životnu sredinu, Banja Luka

[18] Gnjato S., Popov T., Trbić G., Ivanišević M. (2019) Climate Change Impact on River Discharges in Bosnia and Herzegovina: A Case Study of the Lower Vrbas River Basin. In: Leal Filho W., Trbic G., Filipovic D. (eds) Climate Change Adaptation in Eastern Europe. Climate Change Management. Springer, Cham. https://doi.org/10.1007/978-3-030-03383-5_6

[19] Gnjato, S. (2018). Analysis of the Water Discharge at the Sana River. Herald, 22, 103-116. doi:10.7251/HER2218103G

[20] Majkić, J. K. \& Urošev, M. (2014). Trends of Mean Annual and Seasonal Discharges of Rivers in Serbia. Journal of the Geographical Institute "Jovan Cvijić" SASA, 64(2), 143-160.

[21] Ulaga, F., Kobold, M. \& Frantar, P. (2008). Trends of River Discharges in Slovenia. IOP Conference Series Earth and Environmental Science, 4(1), 012030.

[22] Čanjevac, I. \& Orešić, D. (2015). Contemporary Changes of Mean Annual and Seasonal River Discharges in Croatia. Hrvatski geografski glasnik, 77(1), 7-27.

[23] Radevski, I., Gorin, S., Taleska, M. \& Dimitrovska, O. (2018). Natural Regime of Streamflow Trends in Macedonia. Česká geografická společnost, 123(1), 1-20.

[24] Crnogorac C., Rajcevic V. (2019) Climate Change and Protection Against Floods. In: Leal Filho W., Trbic G., Filipovic D. (eds) Climate Change Adaptation in Eastern Europe. Climate Change Management. Springer, Cham. https://doi.org/10.1007/978-3-030-03383-5_9

[25] Рајчевић, В., Црногорац, Ч.Б. (2011). Ријека Врбања - физиогена својства слива и ријечног система, ATRPRINT, Бањалука.

[26] Emina Hadžić, Nusret Drešković,2014, Analiza uticaja temperaturnih i padavinskih oscilacija na riječne protoke u Sarajevskoj kotlini, Vodoprivreda, vol. 46, str. 65-75

[27] Langović, M., Manojlović, S. \& Čvorović, Z. (2017). Trends of Mean Annual River Discharges in the Zapadna Morava River Basin. Bulletin of the Serbian Geographical Society, 97(2), 19-45.

[28] Оцокољић, М. (1994). Цикличност сушних и водних периода у Србији. Посебна издања, Књига 41. Београд: Географски институт „Јован Цвијић“, САНУ. 